\title{
Genotoxicity and DNA Repair Indicative in Blood Cells after Occupational Exposure to lonizing Radiation
}

\begin{abstract}
Ronald Gerard Silva1, Marcus Vinícius Oliveira Barros Alencar2,3, Jadson Silva Teixeira, Reyca Rodrigues e Silva ${ }^{3}$, Márcia Fernanda Correia Jardim Paz ${ }^{2,3}$, João Marcelo de Castro e Sousa ${ }^{4}$, Rai Pablo Sousa de Aguiar ${ }^{3}$, Ricardo Melo de Carvalho ${ }^{3}$, Antonio Luiz Gomes Junior ${ }^{3}$, Ana Maria Oliveira Ferreira da Mata ${ }^{3}$, José Victor de Oliveira Santos ${ }^{3}$, Md. Torequl Islam 2,3,5, Paulo Michel Pinheiro Ferreira2,6,
\end{abstract} Ana Amélia de Carvalho Melo-Cavalcante ${ }^{2,3}$, Jaqueline Nascimento Picada ${ }^{1}$

\section{Abstract}

Occupational exposure to ionizing radiation (IR) can damage DNA. The study evaluated the genotoxic profile and repair indicatives of DNA from peripheral blood lymphocytes of health workers exposed occupationally to IR by adopting comet assay. Biomonitoring was done with ninety individuals; among them 45 were health professionals and the rests were non-professionals. Blood samples were collected after 48 h ( $2 \mathrm{~d}$; non-exposed) and $168 \mathrm{~h}$ (7 d; exposed). The $7 \mathrm{~d}$ IR exposed group significantly increased in the rates and frequency of damage, while $2 \mathrm{~d}$ unexposed group exhibited more than $20 \%$ of DNA repair as compared to the respective control groups. The DNA damage was observed in more significant to the younger workers (18-27 y). However, the hematological abnormalities were not observed, despite of their positive correlation in genotoxic profile. Significant and positive correlations were observed in relation to the used medicaments, low consumption of vegetables as well as the type and place of work. In conclusion, biomarkers involved in comet assay can be applied in biomonitoring of genetic instability, including IR induced phenomena.

\section{Introduction}

Human cells are daily exposed to risk of damage to the genetic material, sources of whose include exogenous (e.g. - plant toxins, UV, X and gamma rays, mutagenic chemicals, chemotherapeutic agents and viruses) and endogenous (reactive oxygen/nitrogen species, estrogen
1 Postgraduate Program in Cellular Biology Applied to Health (PPG Bio Saúde), Lutheran University of Brazil, Canoas, Brazil.

2 Northeast Biotechnology Network (RENORBIO), Post-Graduate Program in Biotechnology, Federal University of Piauí, Teresina (Piauí)-64.049-550, Brazil.

3 Laboratory of Genetical Toxicology, Federal University of Piauí, Teresina (Piauí)-64.049-550, Brazil.

4 Department of Biological Sciences, Federal University of Piauí, Picos-64.049-550, Brazil.

5 Department of Pharmacy, Southern University Bangladesh, Mehedibag (Chittagong)-4000, Bangladesh.

6 Department of Biophysics and Physiology, Federal University of Piauí, Teresina (Piauí)-64.049-550, Brazil.

\section{Contact information:}

Md. Torequl Islam.

Đ rbiotufpi.br@gmail.com

\section{Keywords}

Occupational Exposure; Ionizing Radiation; Genetic Damage; DNA Repair. 
metabolites, deamination, alkylations and so on). The increased levels of DNA damage and inefficient repair mechanisms are molecular events of many pathogenesis and diseases such as neurodegenerative diseases and cancer [1]. Genomic instability leads to the accumulation of mutations, is the initial step in the process of carcinogenesis. Recent data point to an association between genetic changes and cancer [2].

IR causes direct damages to the DNA, with the formation of radicals that generate lesions, such as single and double breaks in DNA strands, as well as change in bases. The overall outcomes are the bad effects on cell cycle, the repair capacity of genetic materials or apoptosis [3], and proceeding on oxidative damage to DNA, lipids, proteins and cell essential metabolites, with changes in the expression of proteins, metabolites, as well as in epigenetic events [4]. In this context, the biological effects of IR in humans exposed at low doses have being of relevant interests in relation to the effects of genetic instability, circulatory problems and in cancer [5].

The comet assay can be applied in clinical monitoring studies, an understanding of the pathogenesis of cancer and degenerative diseases, tumors prediction, radiation and chemotherapies and infertility studies, in addition to evaluation of occupational and environmental risks [1], including IR therapies, and in occupational and/or accidental exposure [2]. Its alkaline version has versatility in the detection of various lesions, for example: single and/or double stranded breaks, apurinic sites, oxidative damage and efficacy of repair [6], allowing the detection of damage at low doses, such as 25 cGy, with response to damage and DNA repair mechanism [7].

By the application of the comet assay in studies of occupational biomonitoring front to damage induced by IR in health professionals, our present study aimed to evaluate the frequency and levels of DNA damage in peripheral blood lymphocytes, along with the DNA repair rates after $7 \mathrm{~d}$ of exposure, and $2 \mathrm{~d}$ of no exposure. The data were also correlated with the hematological parameters and to possible interference factors to the genotoxic analysis, including age, gender, lifestyle, time and place of work.

\section{Matherials and methods}

\section{Ethical aspects}

In this study, the independent variables were manipulated, using blood cells and oral mucosal cells of 45 health professionals (radiologists, technologists and technicians) exposed occupationally to IR for genotoxic evaluation and study of repair. The study is following the international standards and guidelines established for research projects involving human subjects, and was approved by the Ethics Committee on Human Research, based at the Lutheran University of Brazil - ULBRA/RS, CAAE: 38570914.8.0000.5349. The participants of this study, after signing the Term of Free and Informed Consent (TFIC), aware of the importance and the individual benefits of the cellular response evaluation in non-neoplastic cells, answered a public health questionnaire, obeying the protocol published by the International Commission for Environmental Protection to Mutagens and Carcinogens (ICEPMC).

\section{Sampling}

As reported, 45 workers occupationally exposed to $X$-rays in two diagnostic clinics located in Teresina (Piauí), Brazil in 2015 participated in this study. For the control group, 45 people unexposed to IR were selected. All participants in the study agreed to participate and signed the TFIC. Peripheral blood samples were collected in two stages: (1) after weekly occupational exposure to IR and (2) after 48 hours of no exposure, including the weekend. Comet test was performed in the Toxicology and Genetics Laboratory of the Federal University of Piaui (UFPI), Brazil. 


\section{Comet assay}

The alkaline $(\mathrm{pH}>13)$ comet assay was performed with slight modification from the method described byPu et al. [8]. Briefly, blood samples were obtained by veni puncturing from the individuals. Then, the samples were immediately processed. In lab, $5 \mu \mathrm{L}$ of blood (whole blood with heparin) were pipetted, which were added to $95 \mu \mathrm{L}$ of low melting agarose, placed on slides embedded in agarose gel, and covered with cover slips. The slides were then placed in the refrigerator to prevent loss of material following by the removal of the cover slips. Four slides were made for each patient; 2 of those were exposed to $5 \mu \mathrm{M}$ of hydrogen peroxide $\left(\mathrm{H}_{2} \mathrm{O}_{2}\right)$ for 5 min (before exposure to lysis). After $2 \mathrm{~h}$ on lysis solution, the slides were immersed in an alkali buffer $(\mathrm{pH}>13)$ for $25 \mathrm{~min}$. This process allowed the unfolding of the DNA chains through the breaking of the secondary and tertiary structures present in the cell nucleus. After unfolding, the slides were subjected to an electrical current in electrophoresis unit, which induced the migration of DNA fragments in the direction of the electric current for 25 min at 25 volts and $300 \mathrm{~mA}$. All these steps were carried out under indirect and dark place to avoid further damage to the DNA. After electrophoresis, the slides were immediately neutralized with $0.4 \mathrm{M}$ Tris buffer $(\mathrm{pH}$ 7.5), then fixed, washed with distilled water and dried overnight. After hydrating with distilled water for $5 \mathrm{~min}$, the slides were stained with silver solution as described by Chavan et al.[9]. The results were expressed in damage index (DI) and frequency of damage (FD). The ID was obtained by evaluating the tail type, classified from 0 to 4 (50 cells per slide in duplicate) in an optical microscope with the magnification of 100X. Intact nuclei appear round (Class 0 - no damage), while in the damaged cells, the DNA migrates from the nucleus towards the anode during the electrophoresis, showing a "tail" of sedimented fragments, like a comet: Class 1 (minimum damage) to 4 (maximum damage). FD was calculated by subtracting cells with zero damage from 100, that is, based on the number of cells with damage vs those without damage.

\section{Hematological parameters of IR-exposed health workers}

Blood samples were collected for the complete blood count $(C B C)$. The tests were performed according to the protocols established by LabtestDiagnóstica AS.

\section{Statistical analysis}

Normality was assessed by the Kolmogorov-Smirnov test. The t-Student test was used to test the population characteristics. To compare the damage observed in comet assay, post-test Bonferroni Multiple Comparison Test, while the Mann Whitney test was performed for micronucleus assay. The GraphPadPrism software (version: 5.0) was used to carry out these analyzes. All statistical analyzes, including Spearman's rho correlation, were considered significant when $P<0.05$.

\section{Results and discussion}

\section{Characterization of the health workers}

Socio-economical features and the lifestyle of the health professionals unexposed (control group) and exposed to IR are presented in Table 1. By the application of analysis of variance statistical test (ANOVA) and t-Students test, no significance $(P>0.05)$ was observed for age, smoking, use of medicaments, vegetable consumption, in comparison to the individuals exposed to IR. The data point about the importance of risk factors for genetic instability, such as the continued use of medications and, especially, the poor consumption of vegetables.

The nutrients existing in vegetables are considered reducers and/or protective of damage to the DNA. Studies show that supplementation with antioxidant vitamins may reduce genetic instability due to the production of low frequency of micronuclei 
Table 1. General features of the IR exposed and unexposed groups.

\begin{tabular}{|l|c|c|}
\hline Subjectfeatures & $\begin{array}{c}\text { Not exposed } \\
\text { group }(\mathbf{n = 4 5 )}\end{array}$ & $\begin{array}{c}\text { Exposed group } \\
\mathbf{n = 4 5})\end{array}$ \\
\hline Age $^{1}$ & $\begin{array}{c}31.73 \pm 7.44 \\
(18-45)\end{array}$ & $\begin{array}{c}31.47 \pm 7.34 \\
(1947)\end{array}$ \\
\hline & & \\
\hline Gender & \\
\hline Male & $68.9(n=31)$ & $66.7(n=30)$ \\
\hline Female & $31.1(n=14)$ & $33.3(n=15)$ \\
\hline Ethnic ${ }^{2}$ & & \\
\hline Caucasian & 28.9 & 4.4 \\
\hline Black & 31.1 & 31.1 \\
\hline White & 40.0 & 64.4 \\
\hline Mulatto & 22.0 & - \\
\hline Smoking & & \\
\hline
\end{tabular}

\begin{tabular}{|c|c|c|}
\hline \multicolumn{3}{|c|}{ Smoking ${ }^{2}$} \\
\hline Yes & $22.2(n=10)$ & - \\
\hline No & $77.8(n=35)$ & $100(n=45)$ \\
\hline \multicolumn{3}{|c|}{ Alcohol consumption ${ }^{2}$} \\
\hline Yes & $66.7(n=30)$ & $44.4(n=20)$ \\
\hline No & $33.3(n=15)$ & $55.5(n=25)$ \\
\hline
\end{tabular}

Prescribedmedication use ${ }^{2}$

\begin{tabular}{|l|c|c|}
\hline No & $33.3(n=15)$ & $55.5(n=25)$ \\
\hline No & $44.4(n=20)$ & $66.7(n=30)$ \\
\hline Notreported & $33.4(n=15)$ & 0.00 \\
\hline
\end{tabular}

\begin{tabular}{l|c|r}
\hline Vegetable intake & & \\
\hline Yes & $20,0(n=9)$ & $13.3(n=6)$ \\
\hline No & $80.0(n=36)$ & $86.7(n=39)$ \\
\hline
\end{tabular}

PPE use $^{3}$

Yes

$100(45)$

1: Mean \pm standard deviation (SD); 2: Percentage; 3: Personal

Protective Equipment: coat, mask, apron and boots. $P>0.05$ (ANOVA) $t$-Student test; Professionals reported that consumption of alcoholic beverages is related only to an average of 3 bottles of beer on the weekend.

(MN) [10]. Micronutrients hold DNA protection capabilities and, when in nutritional deficiencies, occur the inducing the MN formation [11]. Breakage and loss of chromosomes involve different cellular dysfunctions, such as acentric chromosome fragments resulting from double breaks, MN formation, which can be affected by the co-factors, for examplemagnesium and calcium [12]. However, the individual response to stress may vary along with various conditions, for instance the particular function and the combination of genes, absorption and metabolism, cell death (apoptosis/necrosis, cell cycle control, DNA repair and immune response, and micronutrient deficiencies) [13]. There are reports on the associations between genetic polymorphisms and MN formation, and thus genetic variants may modulate the effects of environmental exposure to genotoxic agents, as well as age, lifestyle characteristics (alcohol, tobacco, folates), cardiovascular diseases and cancer [14].

\section{DNA damage profile in peripheral blood lymphocytes of IR exposed individuals}

Evaluation of DNA damage can be used as an accurate biomarker for quantifying toxicogenetic risks of $I R$, which are also related to the cancer etiologically [15]. Health workers exposed occupationally to IR showed genotoxicity in blood cells significantly ( $P$ $<0.0001)$ where an increase in the rates and frequencies of DNA damage was observed (Figure 1). To evaluate the susceptibility to oxidative damage,

Figure 1: Genotoxicity in health professionals. [Mean \pm SD (100 cells per slide); *** $\mathrm{P}<0.001$ (ANOVA, Bonferroni's multiple comparison test) compared to the control group].

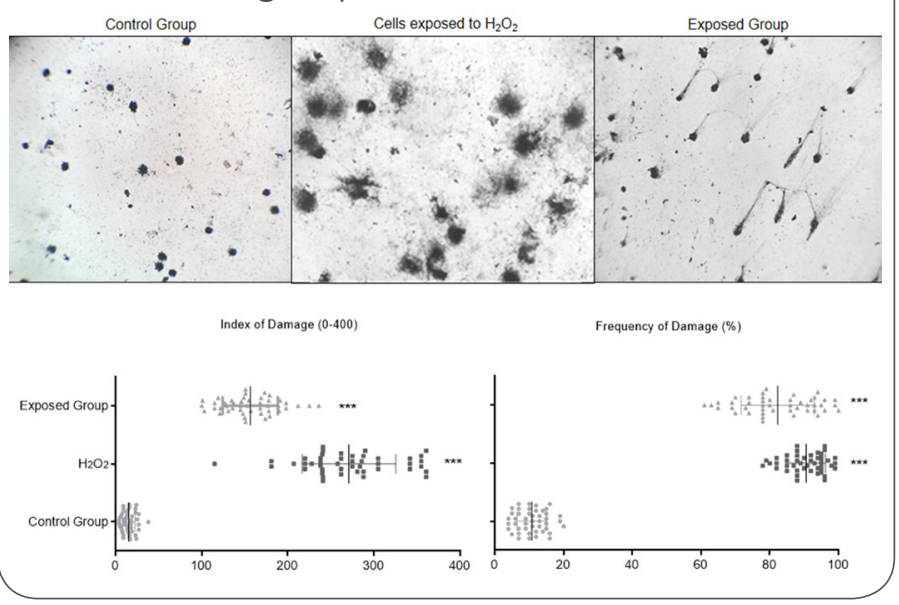


blood cells from health professionals were exposed to $\mathrm{H}_{2} \mathrm{O}_{2}$ and the results showed similarities between the damage seen in cells exposed and unexposed to $\mathrm{H}_{2} \mathrm{O}_{2}$.

In an occupational study, the nuclear medicine physicians showed DNA damage in leukocytes with the application of comet assay. Correlation with smoking was not observed in the study [16]. However, Khisroon et al. suggested that the radiologists' professionals are susceptible to the IR-induced genotoxicity [17].

The comet assay is a simple, rapid, versatile and sensitive method, which indicates the DNA damage and repair capacity [7]. Thus, this assay has been applied in studies of a wide variety of chemicals, biochemicals and even IR induced genotoxic events in test systems including humans [2]. The alkaline version of comet assay is capable to detect various lesions, such as single and/or double stranded, apurinic sites, the oxidative damage in genetic materials [18] even at low IR doses (e.g. - 25 cGy) [19].

IR is evident to cause DNA damage, such as single and/or double breaks, base modifications, crosslinks [20]. The double breaks are more deleterious effects induced by IR and are associated with the acute toxicity and cancer/cancer-induced situations [21], notably, genomic disorganization and phosphorylation of histone $\mathrm{H} 2 \mathrm{AX}$ at serine 130 residues are evident in this kind of breaks [22]. IR also induces DNA damage by mechanisms associated with reactive oxygen species (ROS), which can lead to lipid peroxidation [23]. The hydroxyl radical $(\bullet \mathrm{OH})$ can be produced by UV and IR, which may cause production of other ROS. The ultimate results are the lesions in DNA [24].

The cytogenetic impact of $\mathrm{X}$-rays, even at low doses (5-3 Gy), or disclosed to induce DNA damage, especially in the assessment of chromosomal abnormalities [25]. The radio-sensitivity can be attributed to the increase of chromosomal aberrations and changes in DNA repair [26].

\section{DNA repair profile in peripheral blood lymphocytes after IR exposure}

Humans are continually exposed to IR from natural and anthropogenic sources, with the induction of several biological effects at high and low doses (50$500 \mathrm{mGy}$ ), but with individual variations of responses by proteomic differences between individuals [27], due to the gene polymorphism associated with DNA damage, as well as those involved in the repair [28]. Health professionals from the clinics, after a week of occupational exposure to IR, showed increased rates and frequency of damage in peripheral blood lymphocytes, when compared to nonexposed workers, as shown in Figure 1.

It was also observed that, after 48 h, in the weekend, these damage frequencies have been reduced by about $20 \%$, suggesting repair, as noted by significances between the increased frequency of injury observed after one week of exposure and the ones observed after $48 \mathrm{~h}$ (without exposure). These data were corroborated with the percentage of DNA repair, calculated by considering the damage observed during one week of exposure, which reached, on average of a $20 \%$ repair (Figure 2 ). In its alkaline version, the comet assay estimates the DNA injury

Figure 2: Frequency of Damage (FD) and percentage of DNA repair in peripheral blood lymphocytes of health workers exposed to ionizing radiation (IR).

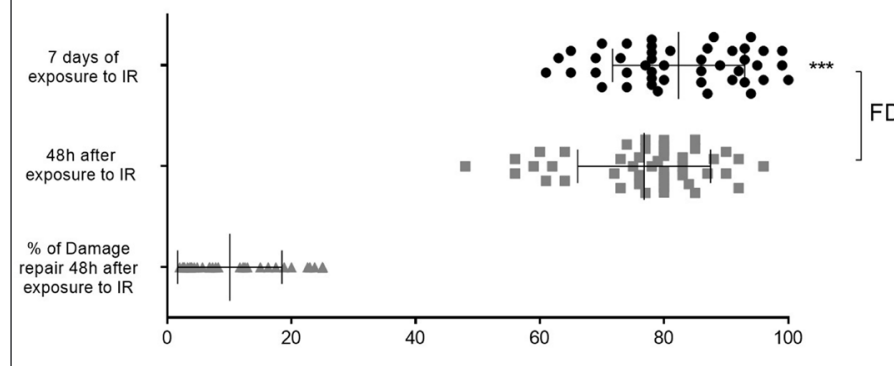

Values are mean \pm SD (100 cells per slide). FD $=$ frequency of damage. ${ }^{* * *}$ $\mathrm{P}<0.001$ (ANOVA, Bonferroni's multiple comparison test) compared to the group $48 \mathrm{~h}$ after exposure to IR. The \% of DNA repair was calculated using the formula: \% R = [\{FD after a week of exposure - FD $48 \mathrm{~h}$ after a week of exposure\} / FD after a week of exposure] X 100. 
Figure 3: Possible DNA repair in blood cells of health professionals exposed occupationally to the $I R$, considering the types of damage (0-4).

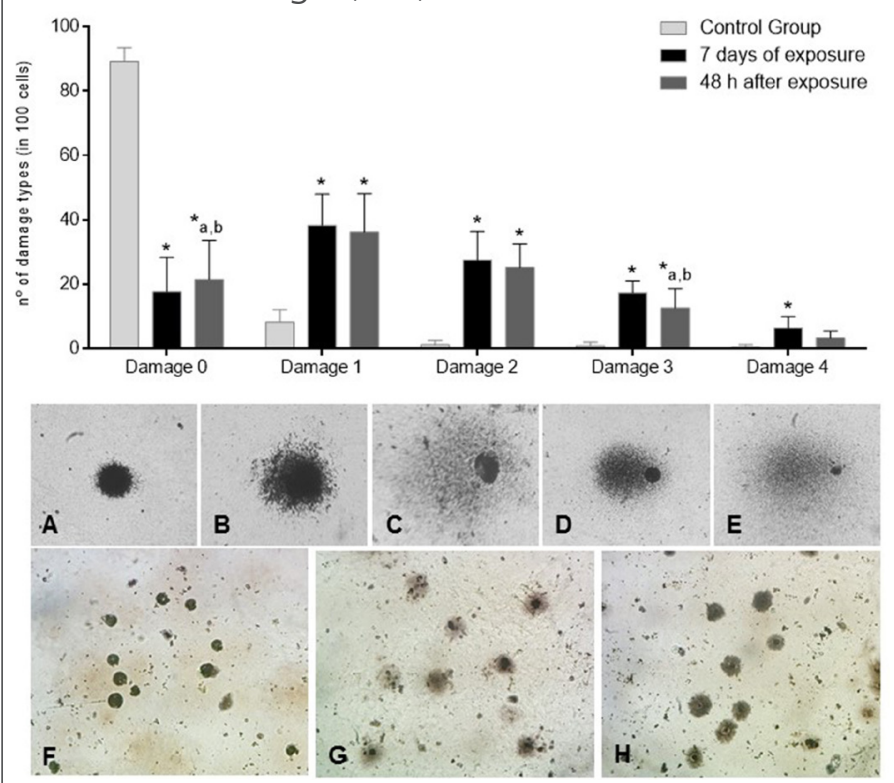

Values are mean \pm SD (100 cells per slide). ${ }^{*} \mathrm{P}<0.05$ (ANOVA, Bonferroni's multiple comparison test) compared to the group 7 days of exposure (a) and $48 \mathrm{~h}$ after exposure (b). Damage types 0 (A), 1 (B), 2 (C), 3 (D) and 4 (E). Photomicrograph profile of control group (F), 7 days of exposure (G) and 48 $h$ after exposure $(H)$.

and also determines the repair effectiveness with predictive value for clinical studies on IR effects, with responses in individualized cells, once it is a rapid method for detecting DNA damage and repair possibilities in cell lines that decrease the length of tail after 60 minutes application of radiation [29].

The biochemical mechanisms of DNA repair have been well characterized by Aziz Sancar and Paul Modrich[30], but how these mechanisms are regulated, still to be found out [31]. As characterized in the previous item, IR induces different DNA lesions, once the double breaks are the most common and lead to genetic instability, cell death and cancer. The double breaks induced by the IR repair by homologous and non-homologous recombination [32], in the $\mathrm{G} 2$ phase of the cell cycle [33].

Repair indicative were also observed by the analysis of the types of damage (0-4) of the DNA du- ring the observation period. The data presented in Figure 3 indicate significance $(P<0.05)$ in damages graded by 1, 2, 3 and 4 regarding to the control group. More frequent damages were observed in type 1, 2 and 4 .

It should be emphasized that failures in these repair mechanisms can lead to DNA damage and apoptosis [34], as well as changes in DNA (mutations, chromosomal aberrations, translocations) [35]. However, in tumor cells, the repair is constituted a resistance to radiotherapy [36]. An understanding of cell responses to the DNA damage is important for the comprehension of the molecular mechanisms for post-transcriptional modification factors involving in responses to the cellular damage, primarily related to double strand breaks (Figure 4). The repair path for double failures can be attributed to the repair by homologous recombination (HR) and non-homologous recombination (NHR), which occurs in the $G 2$ period of the cell cycle. The phosphorylated RPA replication protein is a marker of response to IR [33]. The double breaks are potentially lethal, since they cannot be repaired, leading to genomic instability. One study indicates that the ATM proteins are the sensor for IR and responsible for HR repair [37].

The responses to DNA damage are important for the maintenance of the genome, such as DNA repair, apoptosis and senescence. The apoptosis are often used as cancer risks and are controlled by the p53 protein [38]. Notably, p53, p63 and p73 proteins, and transcription factors involved in the induction of the cell cycle arrest are important, emphasizing that no repair or incorrect repair leads to apoptosis [7]. The repair of nuclear injury induced by IR depends on the mitochondria, as they consume energy (ATP), and cells exposed to radiation increase oxygen consumption, with a reduction in the kinases phosphorylation (CDK1), which operate in the cell cycle and nuclear DNA repair. These aspects are important for the understanding of genotoxic stress conditions [39]. 
Figure 4: An overall ionizing radiation induced cellular events

\section{IR}

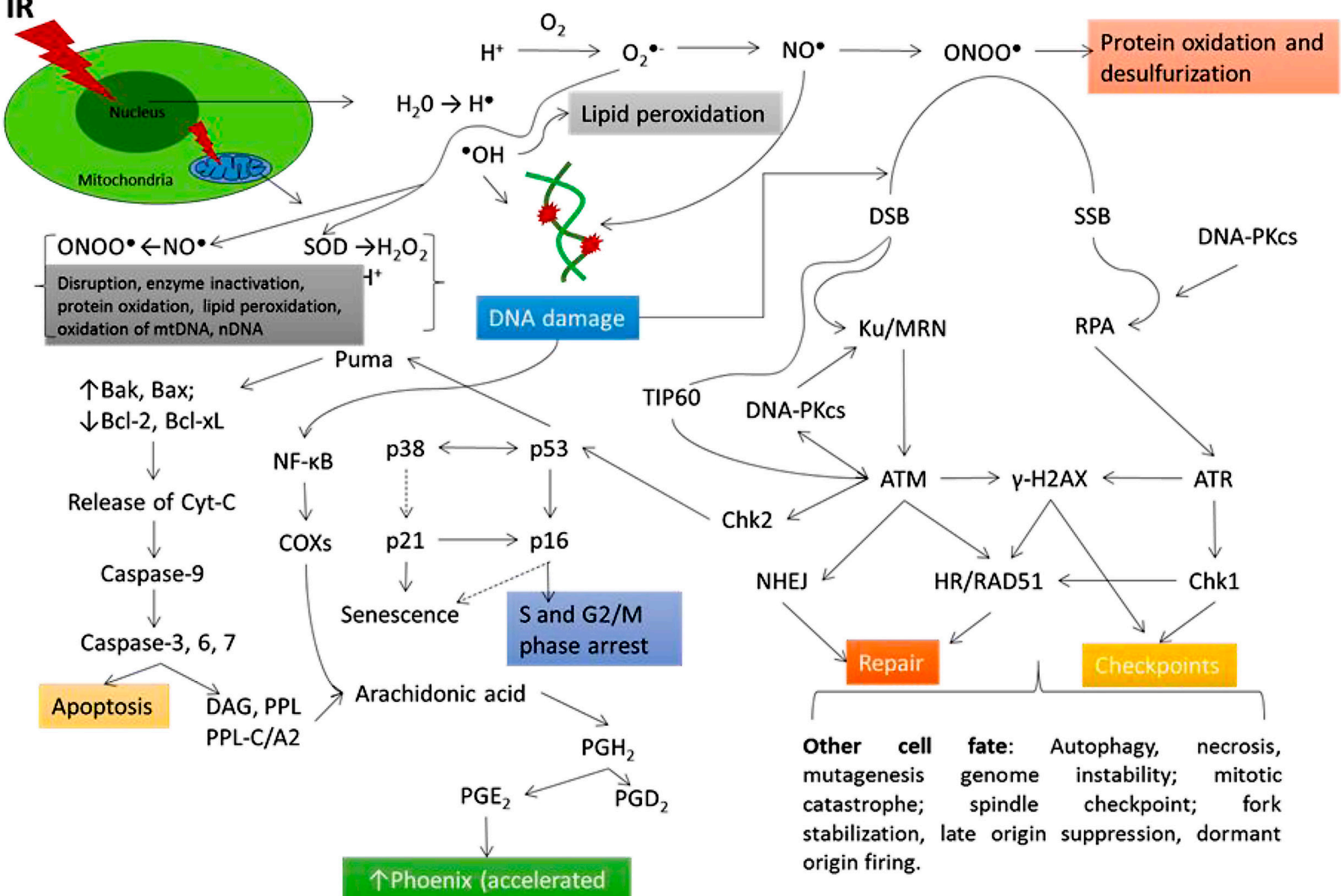

[Reactive species are produced after radiolysis of water. Among them, $\bullet \mathrm{OH}^{\circ}$ and $\mathrm{NO} \bullet$ are responsible to cause DNA breakage (DSBs and SSBs). Additionally, $\bullet$ OH and ONOO ${ }^{\bullet}$ also cause lipid peroxidation and protein oxidation, respectively. DSBs via NHEJ, while SSBs by Chk1 and HR/RAD51 may undergo DNA repair process. However, via Chk2 pathway, DSBs can stimulate the p53; which eventually stimulate the activity if Puma and up-regulates Bak and Bax by down-regulating Bcl-2 and BCl-xL proteins. It causes the release of Cyt- $C$, and an up-regulation of Caspase-9. This process turns to up-regulation of Caspase-3, 6 and 7; among which Caspase-3 and 7 are responsible for apoptotic cell death. Additionally, it causes the production of DAG, PPL, PPL-C/A 2 , which along with the NF-KB pathway may act on arachidonic acid and results the synthesis of inflammatory mediators such as $\mathrm{PGH}_{2}$ followed by $\mathrm{PGD}_{2}$ and $P G E_{2}$. The latter one is responsible for the stimulation of Phoenix activity, which actually accelerates the tumor repopulation. Otherwise, the protein p53 stimulating the activity of p21 and p16 are responsible for cell senescence. Cell cycle arresting, mainly in S and G2/M phases also occurred by the up-regulation of p16. Cellular other fates like - autophagy, necrosis, mutagenesis genome instability, mitotic catastrophe, late origin suppression and dormant origin firing are also to be noted down. Superoxide $\left(\mathrm{O}_{2}^{\bullet-}\right)$ radical by the help of mitochondrial SOD converts into the neutral molecule, $\mathrm{H}_{2} \mathrm{O}_{2}$. However, the $\bullet \mathrm{OH}^{\circ}$ and $\mathrm{ONOO}{ }^{\bullet}$ in mitochondria also cause the same events those of the nucleus. Finally, breakage of the mtDNA, induced nDNA, alteration of membrane potential, mitochondrial de-energisation, disruption of membrane and inactivation of mitochondrial enzymes are evident to occur.] 
Table 3. Hematological parameters of exposed and unexposed groups to ionizing radiation.

\begin{tabular}{|c|c|c|c|c|c|c|c|}
\hline Groups & Gender & Parameters & Minimum & Maximum & Mean & SD & Reference values \\
\hline \multirow{22}{*}{$\begin{array}{l}\text { Not } \\
\text { exposed }\end{array}$} & \multirow{11}{*}{ M } & Hemoglobin & 14.0 & 17.6 & 15.5 & 1.0 & \multirow{44}{*}{$13.0-27.5$} \\
\hline & & Erythrocytes & 4.4 & 5.5 & 4.9 & 0.2 & \\
\hline & & Platelets & 22000.0 & 420000.0 & 281452.5 & 60114.4 & \\
\hline & & Hematocrit & 41.0 & 50.0 & 45.6 & 2.4 & \\
\hline & & Leucocytes & 2700.0 & 7600.0 & 5588.2 & 1073.9 & \\
\hline & & Basophil & 0.00 & 0.00 & 0.0 & 0.0 & \\
\hline & & Eosinophil & 0.00 & 5.0 & 1.6 & 1.0 & \\
\hline & & Rod cells & 0.00 & 2.0 & .1 & 0.4 & \\
\hline & & Segmented Neutrophils & 43.0 & 68.0 & 58.0 & 5.8 & \\
\hline & & Lymphocytes & 30.0 & 48.0 & 37.0 & 4.7 & \\
\hline & & Monocytes & 1.0 & 5.0 & 3.0 & 1.2 & \\
\hline & \multirow{11}{*}{$\mathrm{F}$} & Hemoglobin & 11.1 & 16.0 & 13.7 & 1.2 & \\
\hline & & Erythrocytes & 4.0 & 5.1 & 4.6 & 0.2 & \\
\hline & & Platelets & 200000.0 & 430000.0 & 281756.4 & 55867.7 & \\
\hline & & Hematocrit & 36.0 & 45.0 & 42.2 & 2.1 & \\
\hline & & Leucocytes & 3200.0 & 52000.0 & 7888.4 & 11064.7 & \\
\hline & & Basophiles & 0.0 & 0.0 & 0.0 & 0.0 & \\
\hline & & Eosinophil & 1.0 & 5.0 & 2.2 & 1.2 & \\
\hline & & Rod cells & 0.0 & 2.0 & 0.2 & 0.5 & \\
\hline & & Segmented neutrophils & 46.0 & 68.0 & 56.4 & 5.3 & \\
\hline & & Lymphocytes & 33.0 & 46.0 & 39.5 & 4.4 & \\
\hline & & Monocytes & 1.0 & 5.0 & 2.4 & 1.3 & \\
\hline \multirow{22}{*}{ Exposed } & \multirow{11}{*}{ M } & Hemoglobin & 11.1 & 16.0 & 14.1 & 1.1 & \\
\hline & & Erythrocytes & 4.00 & 5.10 & 4.6 & 0.2 & \\
\hline & & Platelets & 190000.0 & 430000.0 & 270346.8 & 42845.6 & \\
\hline & & Hematocrit & 36.0 & 48.0 & 43.0 & 2.9 & \\
\hline & & Leucocytes & 3200.0 & 52000.0 & 7212.5 & 9498.8 & \\
\hline & & Basophiles & 0.0 & 0.0 & 0.0 & 0.0 & \\
\hline & & Eosinophil & 0.0 & 5.0 & 1.9 & 1.1 & \\
\hline & & Rod cells & 0.0 & 2.0 & 0.2 & 0.5 & \\
\hline & & Segmented neutrophils & 43.0 & 68.0 & 57.7 & 6.2 & \\
\hline & & Lymphocytes & 30.0 & 48.0 & 37.7 & 5.4 & \\
\hline & & Monocytes & 1.0 & 5.0 & 3.0 & 1.4 & \\
\hline & \multirow{11}{*}{$\mathrm{F}$} & Hemoglobin & 11.1 & 15.0 & 13.2 & 1.0 & \\
\hline & & Erythrocytes & 4.0 & 5.1 & 4.5 & 0.3 & \\
\hline & & Platelets & 22000.0 & 420000.0 & 299785.7 & 84683.4 & \\
\hline & & Hematocrit & 36.0 & 45.0 & 40.3 & 3.0 & \\
\hline & & Leucocytes & 4050.0 & 7900.0 & 5473.6 & 1100.6 & \\
\hline & & Basophiles & 0.0 & 0.0 & 0.0 & 0.0 & \\
\hline & & Eosinophil & 0.0 & 4.0 & 1.2962 & 0.8 & \\
\hline & & Rod cells & 0.0 & 1.0 & 0.2 & 0.4 & \\
\hline & & Segmented neutrophils & 47.0 & 65.0 & 58.0 & 5.8 & \\
\hline & & Lymphocytes & 31.0 & 43.0 & 36.3 & 3.5 & \\
\hline & & Monocytes & 1.0 & 4.0 & 2.8 & 1.0 & \\
\hline
\end{tabular}




\section{Hematological evaluation of patients exposed to IR}

The biological effects of $I R$ are primarily derived from the generation of electrons that generate free radicals and subsequent attack DNA, proteins and lipids. However, this situation can be derived directly by the deposition and energy, generating systemic effects [40]. Studies on doses and effects of IR in relation to the cytopenia (leucopenia, thrombocytopenia), as hematopoietic cell responses front to the chronic exposure, have been proposed for different types of blood cells to measure the damage [41]. In our study, no changes were observed in hematological parameters in exposed and unexposed individuals within the observation period (Table 2). However, a decreased level in hemoglobin content and red blood cells were observed in the exposed group in comparison to the control group (data not shown).

Blood cells reduce oxidative stress in DNA damage from blood mononuclear cells by phosphorylation of histone $\mathrm{H} 2 \mathrm{AX}$, recruit repair, which indicates that a large amount of hemoglobin protects against oxidative damage to DNA [42]. The phosphorylation of histone H2AX is an earlier event to repair DNA breaks induced by IR to maintain the genetic stability [43].

\section{Correlations between the genetic damage in relation to age, gender and lifestyle with genotoxic and hematological biomarkers}

Low doses of IR inducing oxidative damage, initiate responses partially by endogenous antioxidants, with heterogeneity in biological matrices, species, and age. However, there are adaptations to antioxidant responses [44]. Oxidative damage can cause disruption of biopolymers [45], and may affect proteins, protein complexes and lipids [46].

For the analysis of possible differences between the mean ages in relation to genotoxic damage, the ID and FD were used. The data not only points
Figure 5: DNA damage according to age of the individuals in peripheral blood lymphocytes. A: ID (index of damage); B: FD (frequency of damage). ANOVABonferroni's test. ${ }^{* *} p<0.001$ compared to control group $(\mathrm{N}=45)$. ${ }^{\mathrm{a}, \mathrm{b}}$ compared to age intervals of 18 to 27 and 28 to 37.

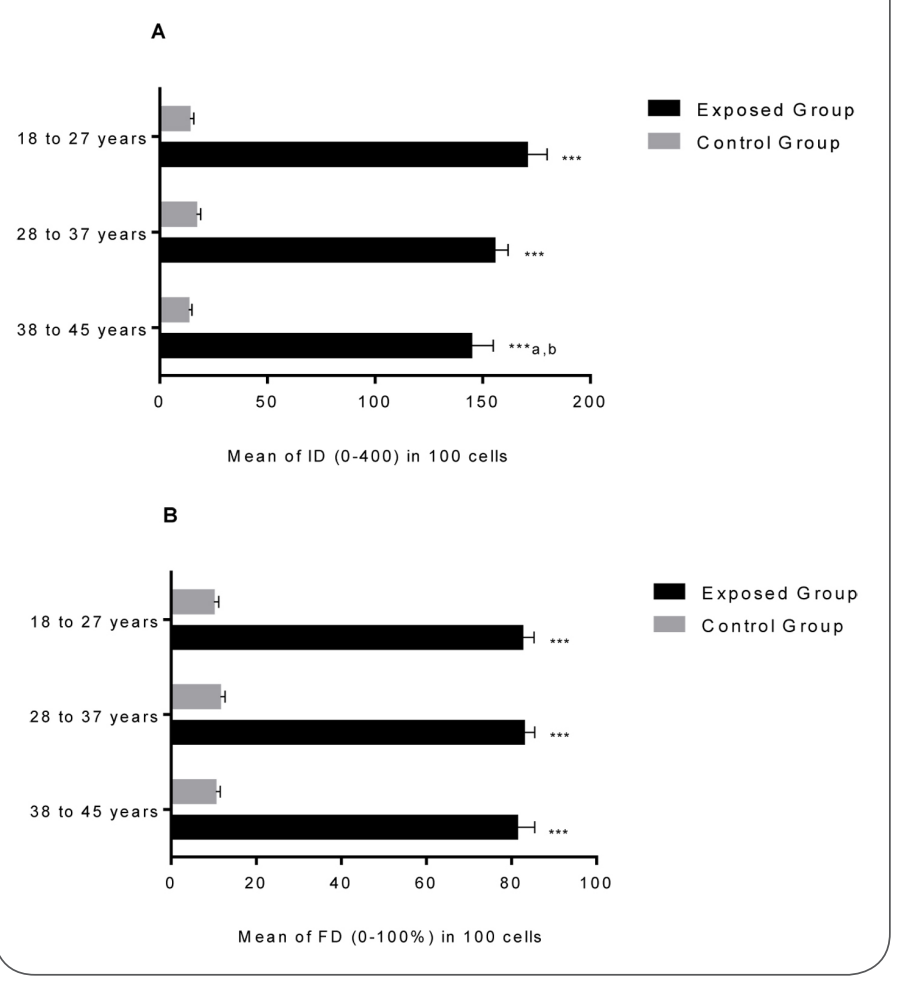

genotoxicity in workers exposed to X-rays, when compared to unexposed group, but also indicate that workers in mean age of 18-27 y were more susceptible to DNA damage induced by occupational exposure to X-rays (Figure 5A and 5B). Studies show that the environmental, occupational, dietary and lifestyle effects may be important in clinical analysis of risk of DNA damage, which can be evaluated by the comet assay [47]. It is noteworthy that, the repair capacity of single and double strand breaks in peripheral blood decrease with the age of the individuals [7], despite of having a significant positive association [48].

Studies show an association between the risk of IR (average of $1.5 \mathrm{~Gy}$ ) on the induction of menin- 
gioma in smokers and nonsmokers as well as in relation to gender. The data indicate significant risks for smokers and for women [49].

Although an exposure to IR is relevant for diagnosis, but the cytotoxic and genotoxic harms may occur with a number of chemical agents, individually or synergistically with IR [50]. Otherwise, the adaptive responses are the phenomena with IR exposure, related to the variability in the expression of genes, endocrine and hormonal factors [51, 52]. In this context, not only diagnostic assays but also the understanding of the influence of environmental factors, lifestyle and clinical investigations are crucial for factors in bio-genetic monitoring [47].

With the application of statistic of Speraman's rho correlation, positive and significant correlations between lifestyle (Table 1) with the genotoxic biomarkers were observed. Corroborating with the hypothesis that occupational exposure to IR has genotoxicity risks, rising indices and frequency of damage (Figure 1), the data showed positive correlations between these parameters of genotoxicity with the type and time of work. However, the genotoxicity observed was also correlated with the use of prescription drugs and with the low consumption of vegetables (Table 3). In our study, a positive and significant correlation was observed between hematological parameters and genotoxicity biomarkers.

Multiple nutrients and its interactions, optimize genomic stability and DNA repair capacity [53]. The increased levels of DNA injury and inefficient repair mechanisms are molecular events of many diseases, including cancer and neurodegenerative diseases [1].

Pharmaceutical drugs can cause genotoxic damage and/or carcinogenic effects, and therefore should be considered in the evaluation of the risk/ benefit ratio [54]. Many pharmaceutical formulations are evident to induce toxic phenomena in various organs. Therefore, investigations of the molecular mechanisms are necessary, aiming to the benefits of the therapeutic potential [55]. Hopefully, regulatory agencies, notably in Europe and in US are always
Table 3. Correlations between the life style and biomarkers.

\begin{tabular}{|c|c|c|}
\hline Parameters & $\begin{array}{l}\text { Sperman's } \\
\text { rho }\end{array}$ & $p$ value \\
\hline \multicolumn{3}{|l|}{ Lifestyle versus biomarkers } \\
\hline $\begin{array}{l}\text { Time of work vs index of } \\
\text { damage }\end{array}$ & 0.637 & $0.001 * *$ \\
\hline Work place vs index of damage & 0.309 & $0.039 *$ \\
\hline $\begin{array}{l}\text { Work place vs frequency of } \\
\text { damage }\end{array}$ & 0.324 & $0.030 *$ \\
\hline $\begin{array}{l}\text { Index of damage vs prescribed } \\
\text { medication }\end{array}$ & 0.339 & $0.000 * *$ \\
\hline $\begin{array}{l}\text { Frequency of damage vs } \\
\text { prescribed medication }\end{array}$ & 0.688 & $0.000 * *$ \\
\hline $\begin{array}{l}\text { Vegetable intake vs index of } \\
\text { damage }\end{array}$ & 0.324 & $0.000 * *$ \\
\hline $\begin{array}{l}\text { Vegetable intake vs frequency of } \\
\text { damage }\end{array}$ & 0.161 & $0.000 * *$ \\
\hline $\begin{array}{l}\text { Haemoglobin mg/dLvs index of } \\
\text { damage }\end{array}$ & 0.249 & $0.000 * *$ \\
\hline $\begin{array}{l}\text { Haemoglobin mg/dLvs frequency } \\
\text { of damage }\end{array}$ & 0.153 & $0.000 * *$ \\
\hline $\begin{array}{l}\text { Erythrocyte count vs index of } \\
\text { damage }\end{array}$ & 0.161 & $0.000 * *$ \\
\hline $\begin{array}{l}\text { Erythrocyte count vs frequency } \\
\text { of damage }\end{array}$ & 0.115 & $0.000 * *$ \\
\hline
\end{tabular}

conscious about this matter [56]. Among the other adverse effects, carcinogenic potentials are the prime concerns in risk assessment. Chronic effects are of major concerns in this context, as it may lead varieties of deleterious events including cancer [1].

\section{Conclusion}

Occupational exposure to IR, even at low doses in health professionals may cause genotoxicity. In this study, we performed alkaline comet assay to investigate two important biomarkers as damage index and frequency of damage of DNA in peripheral blood cells (lymphocytes) in an exposed group and an unexposed group. Our findings suggest that, the DNA damage was more prominent in younger professionals in relation to the old in the exposed 
group. However, an average of 20\% DNA repair was observed, when compared to the frequency of damage after a week of exposure. We founded a correlation between the genotoxic damage and damage type with duration of work, drug as well as micronutrient users. In conclusion, comet assay may be a helpful tool to monitor the genotoxicity induced by IR.

\section{References}

1. V. Gunasekarana, G. V. Raj, P. Chand. A Comprehensive Review on Clinical Applications of Comet Assay. Journal of Clinical and Diagnostic Research 2015; 9: GE01-GE05.

2. A. Collins, G. Koppen, V. Valdiglesias, M. Dusinska, M. Kruszewski, P. Møller, et al. The comet assay as a tool for human biomonitoring studies: The ComNet Project. Mutation Research Review: Mutation Research 2014; 759: 27-39.

3. G. Sulli, R. Di Micco, F. d'Adda di Fagagna. Crosstalk between chromatin state and DNAdamage response in cellular senescence and cancer. Nature Review in Cancer 2012; 12: 709-720.

4. A. J. Reisz, N. Bansa, J. Qian, W. Zhao, C. M. Furdui. Effects of Ionizing Radiation on Biological Molecules-Mechanisms of Damage and Emerging Methods of Detection. Antioxidants \& Redox Signaling 2014; 21: 260-292.

5. W. Rühm, G. E. Woloschak, R. E. Shore, T. V. Azizova, B. Grosche, O. Niwa, S. Akiba, T. Ono, K. Suzuki, T. Iwasaki, N. Ban, M. Kai, C. H. Clement, S. Bouffler, H. Toma, N. Hamada. Dose and dose-rate effects of ionizing radiation: a discussion in the light of radiological protection. Radiation and EnvironmentalBiophysics 2015; 54: 379-401.

6. E. I. Cortes-Gutierrez, M. I. Davila-Rodriguez, J. L. Fernandez, C. Lopez-Fernandez, A. Gosalbez, J. Gosalvez. New Application of the Comet Assay: Chromosome-Comet Assay. Journal of Histochemistry and Cytochemistry 2011; 59: 655-660.

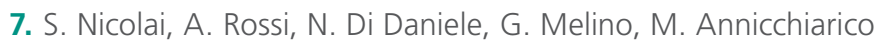
Petruzzelli, G. Raschellà. DNA repair and aging: the impact of the p53 family. Aging 2015; 7: 1050-1065.

8. X. Pu, Z. Wang, J. E. Klaunig. AlkalineComet Assay for Assessing DNA Damage in Individual Cells. Current Protocol in Toxicology 2015; 65:3.12.1-3.12.11.

9. P. Chavan, R. Kumar, R. Kirubagaran, V. P. Venugopalan. Chlorination-induced genotoxicity in the mussel Perna viridis: assessment by single cell gel electrophoresis (comet) assay. Ecotoxicology and Environmental Safety 2016 130: 295-302.

10. P. Thomas, J. Wu, V. Dhillon, M. Fenech. Effect of dietary intervention on human micronucleus frequency in lymphocytes and buccal cells. Mutagenesis 2011; 26: 69-76.
11. Z. Zhang, X. Wang, J. Li, C. Liu, Q. Zhang. Inhibitory effects of Enteromorpha linza polysaccharide on micronucleus of Allium sativum root cells. International Journal of Biology and Macromolecules 2016; 87: 252-255.

12. F. Decarpentrie, O. A. Ojarikre, M. J. Mitchell, P. S. Burgoyne. Recombination between the mouse $Y$ chromosome short arm and an additional $Y$ short arm-derived chromosomal segment attached distal to the X chromosome PAR. Chromosoma 2016; 125: 177-188.

13. D. Harnicek, E. Kampmann, K. Lauber, R. Hennel, A. S. Cardoso Martins, Y. Guo, C. Belka, S. Mörtl, E. Gallmeier, R. Kanaar, U. Mansmann, T. Hucl, L. H. Lindner, W. Hiddemann, R. D. Issels. Hyperthermia adds to trabectedin effectiveness and thermal enhancement is associated with BRCA2 degradation and impairment of DNA homologous recombination repair. International Journal of Cancer 2016; 139: 467-479.

14. C. Bolognesi, S. Bonassi, S. Knasmueller, M. Fenech, M. Bruzzone, C. Lando, M. Ceppi. Clinical application of micronucleus test in exfoliated buccal cells: A systematic review and metanalysis. Mutation Research Review: Mutation Research 2015; 766: 2031.

15. Z. Nikitaki, C. E. Hellweg, A. G. Georgakilas, J.- L. Ravanat. Stress-induced DNA damage biomarkers: applications and limitations. Frontiers Chemistry 2015; 3: 35.

16. E. B. Nuechterlein, L. Ni, E. F. Domino, J. K.Zubieta. Nicotine-specific and non-specific effects of cigarette smoking on endogenous opioid mechanisms. Prog Neuropsychopharmacology in Biolgical Psychiatry 2016; 69: 69-77.

17. M. Khisroon, A. Khan, M. Naseem, N. Ali, S. K. S. B. Rasheed. Evaluation of DNA Damage in Lymphocytes 1 of Radiology Personnel2 by Comet Assay. Advance Publication. Journal of Occupational Health 2015.

18. L. A. Corcuera, L. Arbillaga, A. Vettorazzi, A. Azqueta, A. López de Cerain. Ochratoxin A reduces aflatoxin B1 induced DNA damage detected by the comet assay in Hep G2 cells. Food Chem Toxicol. 2011 Nov;49(11):2883-9.

19. Wilson J, Zuniga MC, Yazzie F, Stearns DM. Synergistic cytotoxicity and DNA strand breaks in cells and plasmid DNA exposed to uranyl acetate and ultraviolet radiation. Journal of Applied Toxicology 2015; 35: 338-349.

20. M. H. Bourguignon, P. A. Gisone, M. R. Perez, et al. Genetic and epigenetic features in radiation sensitivity part I: Cell signalling in radiation response. European Journal of Nuclear MedicineandMolecular Imaging 2005; 32: 229-246.

21. S. Barnard, S. Bouffler, K. Rothkam. The shape of the radiation dose response for DNA double-strand break induction and repair Genome Integrity 2013, 4: 1.

22. Y. Y. Lee, Y. B. Yu, H. P. Gunawardena, L. Xie, X. Chen BCLAF. is a radiation-induced $\mathrm{H} 2 \mathrm{AX}$-interacting partner involved in CH2AX-mediated regulation of apoptosis and DNA repair. Cell Death \& Disease 2012; 3: e359. 
23. H. Yu. Typical Cell Signaling Response to Ionizing Radiation: DNA Damage and Extranuclear Damage. Chinese Journal of Cancer Research 2012; 24: 83-89.

24. M. Dizdaroglu, P. Jaruga Mechanisms of free radical-induced damage to DNA. Free Radical Research 2012; 46: 382-419.

25. A. Suetens, K. Konings, M. Moreels, R. Quintens, M. Verslegers, E. Soors, K. Tabury, V. Grégoire, S. Baatout. Higher Initial DNA Damage and Persistent Cell Cycle Arrest after Carbon Ion Irradiation Compared to X-irradiation in Prostate and Colon Cancer Cells. Frontiers Oncology 2016; 6: 87.

26. H. Mozdarani. Biological Complexities in Radiation Carcinogenesis and Cancer Radiotherapy: Impact of New Biological Paradigms. Genes 2012; 3: 90-114.

27. S. Nishad, A. Ghosh. Dynamic changes in the proteome of human peripheral bloodmononuclear. Mutation Research 2016; 797: 9-20

28. S. Gulati, A. Yadav, N. Kumar, Kanupriya, N. K. Aggarwal, R. Kumar, R. Gupta. Effect of GSTM1 and GSTT1 Polymorphisms on GeneticDamage in Humans Populations Exposed to Radiation From Mobile Towers. Archives of Environmental Contamination and Toxicology 2016; 70: 615-625.

29. D. J. Mckenna, B. A. Doherty, C. S. Downes, S. R. Mckeown, V. J. Mckelvey-Martin. Use of the Comet-FISH Assay to Compare DNA Damage and Repair in p53 and hTERT Genes following Ionizing Radiation. PLoS ONE 2012; 7: e49364.

30. D. Constantinescu-Aruxandei, B. Petrovic-Stojanovska, J. C. Penedo, M. F. White, J. H. Naismith. Mechanism of DNA loading by the DNA repair helicase XPD. Nucleic Acids Research 2016; 44: 2806-2815.

31. N. C. Bauer, A. H. Corbett, P. W. Doetsch. The current state of eukaryotic DNA base damage and repair. Nucleic Acids Research 2015; 43: 10083-10101

32. J. R. Chapman, M. R. Taylor, S. J. Boulton. Playing the end game: DNA double-strand break repairpathway choice. Molecular Cell2012; 47: 497-510.

33. N. I. Nakajima, Y. Hagiwara, T. Oike, R. Okayasu, T. Murakami, T. Nakano, et al. Pre-Exposureto Ionizing Radiation Stimulates DNA Double StrandBreak End Resection, Promoting the Use ofHomologous Recombination Repair. PLoS One 2015; 10: e0122582.

34. D. A. Gewirtz, S. E. Holt, L. W. Elmore. Accelerated senescence: an emerging role in tumor cell response to chemotherapy and radiation. Biochemistry and Pharmacology 2008; 76: 947-957.

35. L. Huang, A. R. Snyder, W. F. Morgan. Radiation-induced genomic instability and its implications for radiation carcinogenesis. Oncogene 2003; 22: 5848-554.

36. E. Mladenov, S. Magin, A. Soni, G. Mliakis. DNA double-strand break repair as determinant of cellular radiosensitivity to killing and target in radiation therapy. Frontiers in Oncology 2013; 3: 113.

37. P. Jeggo, M. F. Lavin. Cellular radiosensitivity: how much better do we understand it? International Journal of Radiation Biology 2009; 85: 1061-1081.
38. J. A. Lemon, K. Taylor, K. Verdecchia, N. Phan, D. R. Boreham. The influence of trp53 in the dose response of radiationinduced apoptosis, dna repair and genomic stability in murine haematopoietic cells. Dose-Response 2014; 12: 365-385.

39. L. Qin, M. Fan, D. Candas, G. Jiang, S. Papadopoulos, L. Tian, G. Woloschak, D. J. Grdina, J. Jian. L CDK1 Enhances Mitochondrial Bioenergetics for Radiation-Induced DNA Repair. Cellular Reports 2015; 13: 2056-2063.

40. R. Radman, E. J. Bland, N. Sangworachat, C. Bucke, T. Keshavarz. Effects of oligosaccharides and polysaccharides on the generation of reactive oxygen species in different biological systems. Biotechnology and Applied Biochemistry 2006; 44: 129-133.

41. I. V. Akushevich, G. A. Veremeyeva, G. P. Dimov, S. V. Ukraintseva, K. G. Arbeev, A. V. Akleyev, A. I. Yashin. Modeling hematopoietic system response caused by chronic exposure to ionizing radiation. Radiation and EnvironmentalBiophysics 2011; 50: 299-311.

42. M. D. Baldissera, M. R. Sagrillo, M. F. de Sá, T. H. Grando, C. F. Souza, G. F. de Brum, S. C. da Luz, S. S. Oliveira, A. L. De Mello, K. Nascimento, E. Tatsch, R. N. Moresco, A. S. da Silva, S. G. Monteiro. Relationship between DNA damage in liver, heart, spleen and total blood cells and disease pathogenesis of infected rats by Trypanosoma evansi. Experimental Parasitology 2016; 161: 12-19.

43. D. Hudson, I. Kovalchuk, I. Koturbash, B. Kolb, O. A. Martin, O. Kovalchuk. Induction and persistence of radiation-induced DNA damage is morepronounced in young animals than in old animals. Aging 2011; 3: 609-620.

44. D. Einor, A. Bonisoli-Alquati, D. Costantini, T. A. Mousseau, A. P. Møller. Ionizing radiation, antioxidant response and oxidative damage: A meta-analysis. Science of the Total Environment 2016; 548-549: 463-471.

45. O. Loseva, E. Shubbar, S. Haghdoost, B. Evers, T. Helleday, M. Harms-Ringdahl. Chronic low dose rate ionizing radiation exposure induces premature senescence in human fibroblasts that correlates with up regulation of proteins involved in protectionagainst oxidative stress. Proteomes 2014; 2: 341-362.

46. W. W. Kam, R. B. Banati. Effects of ionizing radiation on mitochondria. Free Radical Biology and Medicine 2014; 65: 607619.

47. A. Azqueta, J. Slyskova, S. A.S. Langie, I. O' N. Gaivão, A. Collins. Comet assay to measure DNA repair: approach and applications. Frontiers Genetics 2014; 5: 288

48. C. Garm, M. Moreno-Villanueva, A. Bürkle, I. Petersen, V. A. Bohr, K. Christensen, T. Stevnsner. Age and gender effects on DNA strand break repair in peripheral blood mononuclear cells. Aging Cell 2013; 12: 58-66. 
49. P. Flint-Richter, L. Mandelzweig, B. Oberman, S. Sadetzki. Possible interaction between ionizing radiation, smoking, and gender in the causation of meningioma Neuro-Oncology 2011; 13: 345-352.

50. L. Manti, A. D’Arco. Cooperative biological effects between ionizing radiation and other physical and chemical agents. Mutation Research 2010; 704: 115-122.

51. M. - K. Boss, R. Bristow, M. W. Dewhirst. Linking the History of Radiation Biology to the Hallmarks of Cancer. Radiation Research 2014; 181: 561-577.

52. M. Nenoi, B. Wang, G. Vares. In vivo radioadaptive response: A review of studies relevant to radiation-induced cancer risk. Human and Experimental Toxicology 2015; 34: 272-283.

53. M. F. Fenech. Nutriomes and nutrient arrays - the key toNpersonalised nutrition for DNA damage prevention and cancer growth control. Genome Integrity 2010, 1: 11.

54. M. Moretti, M. G. Grollino, S. Pavanello, R. Bonfiglioli, M. Villarini, M. Appolloni, M. Carrieri, L. Sabatini, L. Dominici, L. Stronati, G. Mastrangelo, A. Barbieri, C. Fatigoni, G. B. Bartolucci, E. Ceretti, F. Mussi, S. Monarca. Micronuclei and chromosome aberrations in subjects occupationally exposed to antineoplastic drugs: a multicentric approach. International Archives of Occupational and Environmental Health 2015; 88: 683-695.

55. Z. Hu, J. Wahl, M. Hamburger, A. Vedani. Molecularmechanisms of endocrine and metabolic disruption: An in silico study on antitrypanosomal natural products and some derivatives. Toxicological Letters 2016; 252: 29-41.

56. Y. Hirai, Y. Yamanaka, M. Kusama, T. Ishibashi, Y. Sugiyama, S. Ono. Analysis of the success rates of new drug development in Japan and the lag behind the US. Health Policy 2012; 104: 241246.

Publish in International Archives of Medicine

International Archives of Medicine is an open access journal publishing articles encompassing all aspects of medical science and clinical practice. IAM is considered a megajournal with independent sections on all areas of medicine. IAM is a really international journal with authors and board members from all around the world. The journal is widely indexed and classified Q1 in category Medicine. 